\title{
STRATEGI DAKWAH PESANTREN LUHUR AL-HUSNA DALAM MENJAGA TOLERANSI BERAGAMA DI KOTA SURABAYA
}

\author{
Muhammad Hamdan Yuwafik, Abdul Muhid \\ UIN Sunan Ampel Surabaya \\ Email:afikhamdan@gmail.com, abdulmuhid@uinsby.ac.id
}

Diterima: 01 Juni 2020 | Direvisi: 08 Agustus 2020 | Disetujui: 09 September 2020

\begin{abstract}
This paper attempts to potrait the da'wah strategy of the Luhur Al-Husna Islamic Boarding School in maintaining religious tolerance in the city of Surabaya, as well as its correlation with the Al-Madkhal Ila Ilmi Dakwah book by Al-Bayanuni. The following article is the results of direct field study, with a descriptive analysis approach to the Da'wah strategy model of the Luhur Al-Husna Islamic Boarding School in maintaining religious tolerance. The results of the study indicate that the da'wah strategies used by the Luhur Al-Husna Islamic Boarding School are dialogue, cultural exchange and living together. In addition, the Luhur Al-Husna Islamic Boarding School also uses three da'wah strategies according to Al-Bayanunni, namely al-athifi, al-aqly, and al-hissi. The Da'wah strategy of the Luhur Al-Husna Islamic Boarding School can be said to be successful in maintaining tolerance because it is able to survive and continue to exist today.
\end{abstract}

Keywords: Strategy, Da'wah, Islamic Boarding School Luhur Al-Husna, Tolerance

\begin{abstract}
Abstrak
Tulisan ini mencoba menggambarkan strategi dakwah Pesantren Luhur Al-Husna dalam menjaga toleransi beragama di Kota Surabaya, serta korelasinya dengan kitab Al-Madkhal Ila Ilmi Dakwah karya Al-Bayanuni. Tulisan berikut adalah hasil studi (field research) turun lapangan secara langsung, dengan pendekatan analisis deskriptif terhadap model strategi dakwah Pesantren Luhur Al-Husna dalam menjaga toleransi beragama. Hasil studi menunjukkan bahwa strategi dakwah yang digunakan oleh Pesantren Luhur Al-Husna adalah dialog, pertukaran budaya atau pengetahuan (exchange), dan mondok bersama. Selain itu, Pesantren Luhur Al-Husna juga menggunakan tiga strategi dakwah menurut Al-Bayanunni yakni al-athifi, al-aqly, dan al-hissi. Strategi dakwah Pesantren Luhur Al-Husna bisa dikatakan berhasil dalam menjaga toleransi karena mampu bertahan dan tetap eksis hingga saat ini.
\end{abstract}

Kata Kunci: Strategi, Dakwah, Pesantren Luhur Al-Husna, Toleransi 


\section{Pendahuluan}

Indonesia merupakan sebuah negara yang mempunyai jumlah pemeluk agama Islam terbesar di dunia, selain itu juga mempunyai tingkat pluralitas penduduk yang tinggi. Pluralitas tersebut diantaranya dapat dilihat dari pluralitas budaya, suku, etnik, dan agama (religions). Maka dari itu, sangat dibutuhkan rasa tenggang rasa serta sikap toleransi (tolerance) antar budaya, suku, dan agama untuk menjauhkan dari potensi conflict sehingga menyebabkan perpecahan. Pluralisme agama (religious pluralism) di Indonesia akhir-akhir ini menjadi sorotan. Hal ini disebabkan oleh timbulnya berbagai conflict ditengah masyarakat yang diikuti dengan anarkisme (anarcism) atau kekerasan yang mengatas namakan agama. Anarkisme yang disebabkan oleh perbedaan pandangan, keyakinan ini sangat merugikan bagi keadaan sosial, politik, dan ekonomi di Indonesia. Hal tersebut juga mengkhawatirkan bagi integritas bangsa di dunia Internasional. Berbagai faktor melatarbelakangi terjadinya konflik baik vertikal maupun horisontal terus terjadi. Mulai dari faktor sosiologis, politis, hingga perebutan aset ekonomi. Usaha untuk mencegah munculnya masalah-masalah antar umat beragama yang mengarah pada tindak anarkisme seperti yang sudah dijelaskan di atas, maka diperlukan sikap tenggang rasa dan saling menghormati antar umat beragama di Indonesia. Kondisi penduduk Indonesia yang majemuk, maka sudah tentu interaksi dengan agama, kelompok, etnis, dan suku lain merupakan suatu hal yang pasti terjadi. Maka dengan toleransi sebagai landasan berinteraksi ada harapan besar akan terjalin kesatuan serta kerukunan antar umat beragama di Indonesia.

Toleransi merupakan sikap menghargai pada perbedaan pendapat, pandangan, dan kepercayaan, dengan pendirian dalam diri sendiri. (Hendar Riyadi, 2007:180). Umat Islam sebagai umat mayoritas di Indonesia kini menjadi sorotan utama terkait dengan toleransi kepada umat agama lainnya. Hal tersebut disebabkan penolakan sebagian umat Islam terhadap umat beragama lain. Berkaitan dengan hal di atas dipertanyakan pula eksistensi pondok pesantren dalam pendidikan serta pembinaan nilai toleransi antar umat beragama kepada para santrinya. Padahal agama Islam sangat menjunjung tinggi nilai-nilai toleransi (A'la, 2005).

Pesantren selain sebagai tempat belajar agama para santri juga didefinisikan sebuah lembaga pendidikan agama yang memiliki ciri khas tersendiri (Abdul Rahman Saleh, 2000: 85). Berbicara terkait pengajaran dan pengembangan ajaran agama Islam 
di Indonesia, maka pelibatan pesantren menjadi suatu keharusan yang tidak dapat di tingalkan. Pesantren di Indonesia sudah ada sejak sebelum kemerdekaan. Lembaga pendidikan ini memiliki corak khas pribumi sehingga besar kemungkinan untuk diterima di tengah-tengah masyarakat. Pesantren didirikan dengan keinginan yang kuat guna melakukan transformasi sosial (social transformation) bagi masyarakat (Taufik Abdullah, 1987: 152). Keberadaan pesantren menjadi semakin penting ditengah arus globalisasi (globalization is the process of spread of new elements) dan serbuan teknologi industi 4.0. Pesantren dipercaya sebagai benteng nilai-nilai toleransi di tengah masyarakat Indonesia. Dari sinilah tercermin akan pentingnya (urgensi) keterkaitan pesantren dengan masyarakat. Interaksi sosial-agama yang mendalam antara pesantren dan masyarakat terlihat dalam hal keagamaan, pendidikan, dan kegiatan sosial.

Pesantren Luhur Al-Husna merupakan salah satu profil pesantren yang menjunjung tinggi nilai-niai toleransi antar umat beragama. Hal ini tercermin dalam kehidupan religius Pesantren Luhur Al-Husna yang selalu menanamkan nilai-nilai toleransi kepada santrinya. Hal tersebut kedepan diharap menjadi cikal bakal tumbuhnya nilai toleransi pada para santri, sebelum mereka hidup di tengah-tengah masyarakat kelak setelah lulus dari pesantren. Para santri lulusan Pesantren Luhur AlHusna diharapkan bisa menjadi pribadi yang penuh rasa toleransi dan bisa menjaga nilai-nilai kerukunan antar umat beragama di tengah masyarakat multikultural di Surabaya. Sehingga dapat terciptanya kehidupan yang rukun, damai, dan harmonis.

Pesantren Luhur Al-Husna Surabaya juga memiliki keunikan tersendiri dibandingkan dengan pesantren pada umumnya yang ada di Indonesia. Pesantren ini sering mengadakan kegiatan bersama umat beragama lain di Pondok Pesantren Luhur Al-Husna. Salah satu kegiatan bersama dengan agama lain yaitu kegiatan mondok bersama dan pengajian bersama. Kegiatan ini dirangkai oleh Forum Kerukunan Umat Beragama (FKUB) Surabaya, yang pernah di laksanakan di Pesantren Luhur Al-Husna. Tujuan penulisan artikel ini adalah untuk mengetahui dan menganalisis strategi dakwah Pesantren Luhur Al-Husna dalam menanamkan nilai-nilai toleransi dan mendakwahkannya untuk menjaga kerukunan umat beragama di Surabaya. 


\section{Metode Penelitian}

Dalam melakukan penulisan artikel ini, peneliti menggunakan metode penelitian deskriptif kualitatif. Metode penelitian yang digunakan untuk mengumpulkan data dalam penulisan artikel ini berupa partisipasi dan observasi terhadap strategi dakwah Pesantren Luhur Al-Husna Surabaya dalam menjaga toleransi antar umat beragama. Selain itu, dengan metode berbasis lapangan (field research), yakni dengan melakukan wawancara kepada informan dan dokumentasi. Lokasi penelitian di Pesantren Luhur AlHusna Surabaya. Subjek pada penulisan artikel ini adalah Pesantren Luhur Al-Husna Surabaya. Objek yang diteliti adalah Strategi Dakwah Pesantren Luhur Al-Husna dalam menjaga toleransi beragama di Surabaya.

\section{Hasil Penelitian dan Pembahasan}

\section{Konsepsi Dasar Strategi Dakwah}

Strategi dakwah mengandung dua kata, yakni strategi dan dakwah. Menurut Effendi (1993), strategi adalah perencanaan dan managemen untuk mencapai tujuan. Strategi tidak berfungsi sebagai petunjuk arah saja, melainkan sebuah taktik operasionalnya untuk mencapai tujuan. Pengertian diatas mengandung makna bahwa strategi adalah tahap perencanaan tindakan termasuk dalam penggunaan metode. Strategi disusun untuk mencapai tujuan tertentu. Artinya, sebelum strategi disusun maka tujuan yang jelas sudah harus ditentukan. Tujuan yang jelas adalah alat ukur keberhasilan strategi yang digunakan (Sanjaya, 2006).

Menurut Ansari (1993), dakwah merupakan segala kegiatan orang Islam di dalam (ikhtiar) usaha mengubah dari jalan yang tidak sesuai ketentuan Allah SWT, menuju jalan yang sesuai dengan ketentuan Allah SWT. Strategi dakwah (da'wah strategy) berarti metode, siasat, dan taktik yang dipergunakan dalam aktifitas manusia untuk mengajak umat manusia ke jalan Allah. Prinsip dasar dari berdakwah adalah mempengaruhi mitra dakwah agar mampu mengikuti apa yang diharapkan oleh pendakwah. Konsep strategi dakwah menekan dalam dua hal pokok yakni upaya yang sistematis dengan menggunakan siasat tertentu, serta tujuan dakwah yang ingin dicapai (Syukir, 1983). Dalam buku M. Ali Aziz (2015) menjelaskan bahwa dakwah memiliki enam sifat dasar menurut Ismail Raji Al-Faruqi, yakni pertama, dakwah bersifat persuasif bukan koersif. Kedua, dakwah dimaksudkan kepada pemeluk 
Islam dan non-Islam. Ketiga, dakwah merupakan anamnesis yaitu berupaya mengembalikan fitrah manusia. Keempat, dakwah bukan prabawa psikotropik. Kelima, dakwah adalah rational intelection. Keenam, dakwah adalah rationally necessary. Sifat dakwah yang pertama yakni dakwah bersifat persuasif bukan koersif. Artinya, tidak menggunakan pemaksaan, merusak, bahkan anarkis. Pendakwah akan cenderung melakukan komunikasi dengan pendakatan psikologi mitra dakwah. Tujuannya adalah agar mitra dakwah terpengaruh terhadap apa yang dibicarakan oleh pendakwah. Terlebih jika dakwah yang disampaikan mampu mengubah perilaku mitra dakwah agar lebih dekat dengan Allah.

Sifat dakwah yang kedua adalah dakwah ditujukan untuk pemeluk agama Islam dan non Islam. Hal ini dilakukan sebagai salah satu usaha untuk menunjukkan rahmat Allah, sehingga umat Islam akan lebih yakin dan bertambah kadar keimanannya serta usaha agar umat non-muslim mau untuk menerima kebenaran tentang Islam. Selain itu, hukum berdakwah, yakni fardhu 'ain. Artinya, setiap manusia memiliki kewajiban berdakwah, namun kewajiban tersebut akan gugur ketika sudah dilakukan oleh orang lain. Pada dasarnya, tidak semua orang memang mampu untuk berdakwah, karena keterbatasan keilmuan yang dimiliki. Garis tengahnya adalah, semua manusia diharuskan melakukan dakwah, namun sesuai dengan kemampuan yang dimiliki. Sifat dakwah yang ketiga adalah anamnesis. Artinya, berupaya mengembalikan fitrah manusia. Berdakwah merupakan salah satu cara untuk mengembalikan dan menyadarkan manusia kepada sifat aslinya yakni fitrah yang berarti suci. Sejak lahir sejatinya manusia secara kodrati akan menerima kebenaran.

Sifat dakwah yang keempat adalah dakwah bukan prabawa psikotropik. Cara prabawa psikotropik adalah berdakwah dengan cara yang tidak alami, seperti dengan cara mistis sehingga membuat manusia bertindak diluar kesadarannya (Aziz, 2015). Hal tersebut tidak dibenarkan. Materi dakwah menjadi salah satu hal penting demi tercapainya tujuan dakwah, namun yang tidak kalah penting adalah bagaimana cara pendakwah menyampaikannya. Sifat dakwah yang kelima adalah rational intelection. Artinya, pendakwah mampu menyampaikan pesan dakwah secara rasional dan dapat diterima akal. Pendakwah adalah seorang pemikir, sehingga ia harus mengajak mitra dakwahnya untuk berpikir pula. Islam akan membantu memperkuat dakwahnya dengan pemikiran yang jernih, mampu dicerna oleh logika dan argumentasi (Husnia, 2017). 
Sifat dakwah yang keenam adalah rationally necessary. Artinya, ajaran Islam yang menjadi pesan dakwah adalah ajaran rasional. Berdakwah dengan menyuguhkan nilainilai kritis mengenai kebenaran maupun fakta dan mengetahui relevansinya dengan manusia akan lebih mudah untuk diterima oleh mitra dakwah(Bisri, 1998).

Dalam Kitab Al-Madkhal Ila Ilmi Dakwah karya Al-Bayanuni (2001) dijelaskan terdapat tiga strategi dakwah yakni al-athifi, al-aqly, dan al-hissi. Strategi al-athifi adalah metode dakwah yang memfokuskan pada aspek hati untuk menggerakkan perasaan dan batin mitra dakwah. Artinya, memberikan nasehat dengan kelembutan. Terdapat tiga cara dalam penggunaan strategi sentimentil. Pertama, berdakwah menggunakan nasehat yang baik (mau'idhotul hasanah). Metode ini bisa dilakukan dengan enam cara yakni ceramah atau pidato, mengingat nikmat Allah dan bersyukur, memuji yang berdoa bagi yang dido'akan, senang dan berharap mendapatkan pahala, menepati janji dan menolongnya, dan bercerita perihal cinta yang lembut dan menginspirasi (Al-Bayanuni, 2001). Kedua, berdakwah dengan cara yang jelas, penuh kasih sayang dan mendoakan. Artinya, pendakwah menyampaikan isi dakwahnya menggunakan kalimat yang baik, mampu memberikan pengaruh, dan menginspirasi. Ketiga, berdakwah dengan cara menunaikan hajat, memberikan pertolongan, dan memberikan pelayanan. Artinya, pendakwah melakukan dakwah dengan mengajak untuk menunaikan hajat yang dipraktikkan dengan memberi pertolongan dengan pelayanan yang baik.

Strategi al-athifi dapat digunakan dalam lima kondisi. Pertama, berdakwah terhadap orang-orang bodoh. Kedua, berdakwah terhadap orang yang tidak diketahui keadaannya. Ketiga, berdakwah pada orang yang berhati lemah. Keempat, berdakwah terhadap keluarga. Kelima, berdakwah di tempat yang dulit dijangkau. Selain itu terdapat empat ciri-ciri strategi al-athifi yakni penyampaian yang lembut, memberikan pengaruh dengan cepat terhadap mitra dakwah, meminimalisir permusuhan dan perbedaan, dan penggunaan daerah lebih unggul dalam penyampaiannya (Al-Bayanuni, 2001).

Strategi kedua yakni al- 'aqli. Strategi al- 'aqli adalah cara berdakwah yang fokus terhadap aspek akal dan pikiran. Artinya, menggunakan logika, diskusi, serta contoh dan bukti sejarah. Strategi ini bisa diterapkan dalam empat kondisi. Pertama, digunakan apabila mitra dakwah berada dalam keadaan ingkar secara dzohir. Kedua, 
terhadap orang-orang yang melampui pemikirannya. Ketiga, terhadap orang yang tidak memiliki sifat fanatisme. Keempat, terhadap orang-orang yang bersih dari pengaruh subhat. Selain itu terdapat empat ciri-ciri strategi al- 'aqli yakni berdasarkan rasionalitas atau ilmu kalam, mudah mengubah cara pandang secara rasional, mampu membungkam orang dengan hal yang masuk akal, dan cakupannya lebih sempit karena berbeda dari satu kaum dengan kaum yang lain (Al-Bayanuni, 2001).

Strategi ketiga yakni al-hissi. Strategi al-hissi adalah cara berdakwah berdasarkan pengamatan dan penelitian. Artinya, berpusat pada indera dan percobaan. Strategi ini dapat dilakukan dengan enam cara yakni menggunakan panca indera sebagai cara untuk berdakwah, pembelajaran yang sesuai dengan objek dakwah sesuai profesinya, menjadi panutan dalam memperlajari akhlak dan sikap, mengubah orang agar tidak lagi berbuat mungkar, menceritakan nabi sebagai salah satu contoh. (AlBayanuni, 2001).

\section{Profil Pesantren Luhur Al-Husna}

Dalam dokumen yang tersimpan di Pesantren Luhur Al-Husna dijelaskan bahwa Prof. Dr KH. Ali Maschan Moesa, M.Si pada bulan September 2001 mulai merintis berdirinya pesantren. Nama Al-Husna disematkan oleh beliau pada pesantren yang ia dirikan karena nama Al-Husna memiliki arti nama-nama yang baik. Menurut beliau sifat-sifat Allah SWT harus dibumikan serta dilaksanakan dalam perilaku sehari-hari. Selain itu hal yang menjadi dasar berdirinya Pesantren Luhur Al-Husna adalah pesan dari ayah Prof. Dr. KH. Ali Maschan Moesa, M.Si beserta para gurunya. Pesan tersebut beliau diperintah untuk mendirikan lembaga yang bisa bermanfaat untuk orang banyak, khususnya untuk menimba ilmu agama salah satuya dengan mendirikan pesantren. Pesantren yang telah didirikan oleh Prof. Dr. KH. Ali Maschan Moesa, M.Si ini dapat memberikan manfaat diantaranya:

a. Membekali generasi muda dengan pengetahuan ilmu agama (religion).

b. Membekali para santri dengan akhlak yang sesuai dengan ajaran agama.

c. Membangun sumber daya manusia yang patuh terhadap ajaran agama.

Pesantren Luhur Al-Husna terletak di Kelurahan Jemurwonosari Kec. Wonocolo tepatnya di Jl. Jemur Wonosari Gang Masjid No. 42 Surabaya. Pesantren ini berjarak $100 \mathrm{M}$ dari jalan utama frontage sebelah selatan Universitas Islam Negeri Sunan Ampel 
Surabaya. Pesantren Luhur Al-Husna membawa pengaruh yang cukup besar didalam kehidupan masyarakat khususnya dalam membentengi generasi muda dari arus budaya asing yang ada sekarang ini. Bangunan Pesantren Luhur Al-Husna ini berdiri di tanah 15 x 30 m yang terdiri dari komplek putra dan terdiri dari tiga lantai. Pesantren Luhur Al-Husna memiliki sarana yang cukup baik dan memadai untuk menunjang kegiatan para santri, dalam aktifitasnya sebagai mahasiswa dan aktifitasnya sebagai santri. Pada lantai dasar, terdapat sebuah perpustakaan, dimana dalam perpustakaan ini terdapat buku-buku yang bisa digunakan untuk menunjang pelajaran santri, baik pelajaran pesantren maupun pelajaran di Universitas. Pesantren ini memiliki 31 kamar yang tersebar dilantai dasar sampai lantai 2. Tiap-tiap kamar dihuni antara 4 sampai 6 santri dan tiap-tiap kamar ini juga dilengkapi dengan lemari. Lantai 3 adalah lantai paling atas dipesantren ini. Ruangan pada lantai ini memiliki dua fungsi, yakni sebagai TPQ di sore hari, dan sebagai ruang belajar di malam hari. Selain fasilitas tersebut, pesantren ini juga dilengkapi dengan tempat parkir yang luas.

Pesantren memiliki beberapa kegiatan yang harus diikuti dan dilaksnakan oleh para santri, yang meliputi kitab kajian tafsir Munir setelah sholat subuh, sholat berjama'ah, dan pengajian diniyah setelah maghrib. Selain itu, terdapat pula kegiatan study club. Study club atau Syawir merupakan sebuah diskusi kecil antar santri yang melahirkan pemikiran-pemikiran besar. Diskusi bersama (Study Club) ini juga sebagai wadah berbagi pengalaman diantara para santri. Selain itu, di pesantren juga ada kegiatan ekstrakurikuler yang bertujuan untuk menunjang kegiatan santri dan pemberdayaan santri. Kegiatan ekstrakulikuler tersebut diantaranya banjari, diba'an, dan ro'an.

Pesantren Luhur Al-Husna memiliki ciri khas yang berbeda dari kebanyakan pesantren yang lain. Diantara ciri tersebut yakni, bahwasanya Pesantren Luhur AlHusna dikenal sebagai gudangnya para aktivis kampus. Para aktivis kampus yang berwawasan akademik mayoritas lahir dari pesantren ini. Aktivis Al-Husna meliputi BEM, HMJ, dan organisasi lainnya. Mulai dari aktivis cabang hingga aktivis tingkat wilayah. Dari tingkat Kota bahkan hingga tingkat Provinsi. Ciri khas yang lain yakni dari segi metode pengajarannya. Metode Pengajaran Pesantren Luhur Al-Husna adalah melalui pengajaran sebuah nilai kesadaran, yang dimana biasanya dalam pesantren lainnya selalu menerapkan nilai toleransi. Prioritas utama dari metode ini adalah 
membangkitkan kesadaran yang ada pada tiap diri santri. Santri yang belajar karena tekanan tidak akan menghasilkan proses pembelajaran yang baik.

\section{Makna Toleransi Dalam Agama}

Toleransi (tolerance) merupakan sebuah kata yang berasal dari bahasa latin yaitu tolerantia, yang memiliki arti kelembutan, kelonggaran hati, keringanan dan kesabaran (Hornby As, 1995:67). Toleransi menurut istilah yaitu sikap terbuka, lapang dada, kelembutan, dan sikap suka rela. Dalam pengertian lain toleransi di jelaskan sebagai sikap saling menghormati dan menghargai di tengah keragaman budaya, etnis, dan agama. (Michael Walzer 1997:56). Bisa disimpulkan bahwa toleransi merupakan sebuah sifap menghargai orang lain dalam rangka menggunakan kebebasan hak asasi manusia. Bentuk pengamalan keagamaan dalam bentuk kelompok ini, menurut Joachim Wach, merupakan tanggapan manusia beragama terhadap realitas mutlak yang diwujudkan dalam bentuk jalinan sosial antar umat seagama ataupun berbeda agama. Hal ini untuk memberikan bukti bahwa bagi mereka realitas mutlak merupakan alat penting keberagaman manusia dalam pergaulan sosial, dan ini terdapat dalam setiap agama, baik yang masih hidup bahkan yang sudah meninggal dunia.

Dalam toleransi beragama tidak pula membenarkan keyakinan orang lain yang berbeda keyakinan, sehingga berpotensi timbulnya (conflict religion) permasalahan agama. Rasa saling menghargai perbedaan sebagai wujud kebebasan seseorang dalam memilih pilihan alur hidupnya merupakan inti dalam toleransi beragama. Toleransi beragama tidak ada hubunganya dengan relativitas kebenaran, melepaskan iman, dan menghindari sebuah kepastian (Mahmoud Sadri dan Ahmad Sadri, 2002:203). Nilai toleransi terikat erat dengan kerendahan hati, keramahan, dan kesopanan dalam menghormati budaya, etnis, dan agama lain. Orang yang memiliki jiwa toleran akan selalu melakukan self-criticism (kritik diri) atas keterbatasan pemahaman dan pengetahuan yang dimilikinya (Mahmoud Sadri dan Ahmad Sadri, 2002:18).

Beberapa tahapan-tahapan dalam mengembangkan sikap toleransi beragama yang disampaikan oleh Dadang Kahmad, diantaranya:

a. Mengutamakan aspek-aspek yang sama dalam beragama, dan menjauhkan berdebat terkait aspek-aspek perbedaan dalam beragama. 
b. Menjalankan kegiatan sosial dengan melibatkan pemeluk agama yang berbeda.

c. Membentuk tujuan pendidikan agama (religious education) yang fokus pada aspek fiqhiyah menjadi pendidikan agama yang fokus pada pengembangan aspek universal rabbaniyah.

d. Mengutamakan pendidikan serta bimbingan individu yang membentuk pribadi yang memiliki budi pekerti santun.

e. Menjauhi sifat egoisme dalam berbangsa dan beragama sehingga tidak merasa dan menggagap dirinya yang paling benar (Dadang Kahmad, 2002:151-152).

Bentuk pengembangan sikap toleransi di atas akan berjalan lancar apabila di kembangkan dan di implementasikan melalui lembaga pendidikan. Dalam masyarakat majemuk yang identik dengan masyarakat multikultural yang bermacam-macam keyakinan, budaya, dan etnis cenderung berpeluang besar untuk mengalami sebuah konflik. Namun motto agree in disagreemen menjadi modal social yang kuat dalam (religious tolerence) toleransi beragama.

\section{Strategi Dakwah Pesantren Luhur Al-Husna Dalam Menjaga Toleransi Beragama di Surabaya}

Strategi dakwah Pesantren Luhur Al-Husna menurut pandangan pimpinan dan tenaga pendidik dalam menjaga toleransi beragama di deskripsikan dalam tiga persoalan pokok, antara lain: membentuk aqidah santri secara baik dan benar, Berperan aktif dalam forum kerukunan umat beragama (FKUB) Surabaya, membuat kegiatan pertukaran pengetahuan (exchange) antar umat beragama di Surabaya.

\section{a. Membentuk Aqidah Santri Secara Baik Dan Benar}

Menurut pengasuh Pesantren Luhur Al-Husna sudah sejak dahulu ingin mengembangakan kegiatan pengajian rutin untuk mempelajari ajaran aqidah Islam sebagai bekal keagamaan sejak usia belia. Pengasuh pesantren berharap dengan dasar aqidah yang benar seorang anak akan memiliki dasar agama (religion) yang kuat, agar kelak para santri menjadi orang yang selalu bertaqwa kepada Allah SWT. Maka dari itu tepat pada tahun 1 Januari 2003, Pesantren Luhur Al-Husna mendirikan sebuah lembaga pendidikan Al-Quran sebagai wadah pendidikan usia dini bagi anak-anak di lingkungan Pesantren Luhur Al-Husna. Perlu di ketahui bahwa Pesantren Luhur Al-Husna berdiri di lingkungan yang beragama non-Islam. 
Namun dengan nilai-nilai toleransi Pesantren Luhur Al-Husna masih eksis berdampingan dengan tetangga yang beragama non-Islam.

Pengajaran pendidikan aqidah merupakan dasar bagi setiap muslim. Aqidah merupakan sebuah dasar beragama yang memberikan arah bagi setiap muslim dalam mengarungi kehidupan. Aqidah merupakan diantara perintah utama dalam dakwah Nabi Muhammad SAW. Kegiatan di pesantren yang dilakukan dengan pembiasaan berperilaku luhur, keteladanan, dan kontrol yang baik dengan disiplin peraturan pesantren menjadi faktor utama dalam pembentukan karakter santri yang berbudi mulia (Said Aqil Siradj, 2014:x!). Ketika nabi melakukan dakwah di Makkah dan Madinah pada awal penyebaran agama Islam nabi pertama menyebarkan dahwahnya yang berisi tentang aqidah - akhlaq sesuai dengan wahyu yang diberikan Allah SWT kepada Rosulullah.

Penerapan aqidah di Pesantren Luhur Al-Husna dilaksanakan degan cara pemilihan mata pelajaran yang berkualitas bagi para santri. Para santri pesantren di bekali dengan materi-materi dasar agama dan aqidah yang berkualitas dari kitabkitab ulama Islam (salafu sholih). Penyampaian materi ini dilakukan ketika pelaksanaan kegiatan belajar mengajar (madrasah) setiap hari kecuali hari sabtu dan minggu. Pelaksanaan kegiatan madrasah dimulai pada 18:00 WIB sampai 20:00 WIB khususnya di kelas, dan setiap selesai solat subuh hingga pukul 06:00 WIB. Dalam penyampaian pelajaran disampaikan kajian kitab: Tafsir Munir, Matan Jurumiyah, Matan Bina Wal Asas, dan Fatkhul Qorib Mujib, dan lain-lain. Pengasuh pesantren berharap para santri bisa memahami dengan benar perintah syariat dan larangan-larangan syariat dalam Al-Quran dan hadits (M. Kholili Anam Ketua Pesantren Luhur Al-Husna Wawancara, Surabaya 16 Desember 2019).

Dalam setiap kegitan pembelajaran, santri Pesantren Luhur Al-Husna memahami isi pelajaran yang sudah di sampaikan oleh Asatid secara teoritis dan praktis. Sehingga dapat diterapkan di kehidupan sehari-hari santri secara baik untuk membentuk karakter santri secara benar sesuai syariat Islam. Dalam hal ini Pesantren Luhur Al-Husna menggunakan dakwah bil hikmah. Strategi ini dapat dilihat ketika para santri diwajibkan sholat berjamaah setiap hari di musholla pesantren. Hal ini dimasudkan agar para santri memiliki sifat yang tekun dan sabar. Santri juga ditanamkan sikap saling menghormati antar santri maupun dengan 
Asatid di pesantren (Pengasuh Pesantren Luhur Al-Husna Wawancara, Surabaya 16 Desember 2019). Di atas merupakan deskripsi strategi dakwah Pesantren Luhur AlHusna dalam menjaga toleransi di Surabaya dalam bidang aqidah.

\section{b. Berperan Aktif Dalam Forum Kerukunan Umat Beragama (FKUB) Surabaya}

Forum kerukunan umat beragama (FKUB) Surabaya merupakan wadah persatuan umat berbagai agama yang ada di Surabaya. Sebagai lembaga yang mengurus persatuan agama-agama barang tentu didalamnya banyak terdapat pemuka dari berbagai agama yang mewakili atau representasi dari agama yang ada di Surabaya. FKUB mempunyai peran penting dalam mewujudkan toleransi umat beragama di Surabaya. Budaya toleransi (culture tolerance) yang dimaksud merupakan sikap saling menghormati dan menghargai antar kelompok atau antar individu di masyarakat. Dapat kita lihat di Kota Surabaya sikap saling menghargai antar satu pemeluk agama dengan pemeluk agama lain hidup saling berdampingan tanpa adanya konflik agama satu sama lain. Hal di atas sesuai dengan kondisi yang disampaikan oleh Departemen Agama Republik Indonesia bahwa budaya toleransi diartikan sebagai kondisi hidup dan kehidupan yang mencerminkan suasana damai, tertib, tentram, aman, dan saling menghargai, sesuai dengan ajaran agama dan kepribadian dan dasar negara Indonesia (Depag RI, 1997:20).

Berdasarkan hasil observasi, peran aktif dalam Forum Kerukunan Umat Beragama (FKUB) dalam menjaga toleransi di Surabaya sebagai strategi dakwah Pesantren Luhur Al-Husna dapat di lihat dari: 1). Berbagai kegiatan bersama dengan agama-agama yang ada di Surabaya yang dilaksanakan di Pesantren Luhur A-Husna. 2). Pesantren Luhur Al-Husna Kerap dijadikan wadah untuk belajar bersama-sama dengan umat agama lain. 3). Pesantren Al-Husna menyediakan tempat cuma-cuma untuk umat agama yang tergabung dalam FKUB yang ingin belajar atau meninap di Pondok Pesantren. Tanpa membeda-bedakan agama satu dengan agama yang lain, seperti yang pernah di sampaikan oleh Prof. Dr. Ali Maschan Moesa, M.Si diatas sebuah agama masih lebih tinggi rasa kemanusiaan. Bagaimana kamu merasa menjadi orang yang paling beragama, namun di sisi lain kamu tidak mempunyai rasa kemanusiaan antar sesama manusia. 
Didalam membentuk budaya toleransi (culture tolerance) dalam prespektif teori yang dijelaskan oleh abdul Rahim, tolerace dapat dibangun melalui pendidikan, yaitu pengajaran serta pemahaman kesadaran pada setiap umat beragama untuk melaksanakan nilai toleransi dalam kehidupan sosial. Seperti kesadaran pluralitas Agama (Religion), kesadaran Hak Asasi manusia, dan kesadaran Inklusivisme (Yunus, 2013:6).

\section{c. Membuat Kegiatan Pertukaran Budaya (Exchange) Antar Umat Beragama Di} Surabaya.

Dalam membentuk budaya toleransi banyak cara dapat dilakukan diantaranya yaitu: 1). Memberikan pengenalan, bimbingan (education) pada tiaptiap umat beragama bahwa dalam menjalankan kehidupan beragama tidak harus mempersoalkan perbedaan, baik dalam konteks keyakinan maupun dari konteks implementasi pengamalan keagamaan dalam kehidupan. 2). Menanamkan kesadaran Hak Asasi Manusia bahwa setiap manusia memiliki kebebasan dalam memeluk agama dan kepercayaan yang ingin mereka percayai dengan sepenuh hati. Salah satunya yaitu hak ingin mengetahui ajaran atau belajar agama di Pesantren Luhur Al-Husna. 3). Menanamkan kesadaran inklusivisme yaitu menyakinkan kepada setiap umat bergama, bahwa setiap manusia memiliki perbedan dan persamaan. Para pemuka masing-masing agama menanamkan dan merumuskan niai ajaran agama yang sama yakni saling menghargai, menghormati, seperti yang dikemukaan oleh Pengasuh Pesantren Luhur Al-Husna Surabaya bahwa seluruh agama mengenalkan dirinya sebagai sumber kedamaian, tidak ada agama yang mengajarkan sikap intoleransi.

Strategi dakwah Pesantren Luhur Al-Husna dalam menjaga toleransi di Surabaya yang terakhir dapat dilihat dari kegiatan Exchange kegiatan rutin yang dilakukan oleh santri Pesantren Luhur Al-Husna. Kegiatan exchage ini berfokus pada kesenian atau budaya yang dimiliki oleh masing-masing umat beragama. Santri pesantren Luhur Al-Husna tidak sungkan untuk saling mengajarkan terkait bagaimana cara menabuh Rebana, Samroh kepada umat yang beragama lain. Hal ini dimaksudkan agar umat agama lain tertarik dengan kesenian yang santri 
Pesantren Luhur Al-Husna miliki, agar kita bisa saling belajar dengan masingmasing kesenian dan budaya yang dimiliki.

\section{Korelasi Strategi Dakwah Pesantren Luhur Al-Husna dengan Al-Bayanuni}

Dakwah yang dilakukan oleh Pesantren LuhurAl-Husna sangat sesuai dengan enam sifat dakwah. Pertama, dakwah baersifat persuasif bukan koersif yang artinya tidak menggunakan pemaksaan atau anarkis. Sesuai dengan dakwah yang dilakukan oleh pengasuh Pesantren Luhur Al-Husna dalam mengajak para santri agar membumikan sikap toleransi tanpa paksaan. Kedua, dakwah ditujukan untuk pemeluk agama Islam dan non-Islam. Pesantren Luhur Al-Husna menyebarkan dakwahnya tidak hanya untuk para santri namun juga rutin melakukan dakwah kepada umat beragama lain yang melakukan kegiatan di Pesantren Luhur Al-Husna Surabaya. Artinya, bukan hanya orang Islam yang menjadi sasaran dakwahnya. Ketiga, dakwah bersifat anamnnesis yakni berupaya mengembalikan fitrah manusia. Pengasuh Pesantren Luhur Al-Husna selalu menanamkan ajaran kepada para santri bahwa perbedaan pada setiap manusia itu merupakan hal yang lumrah terjadi kepada setiap manusia. Keempat, berdakwah harus dengan cara yang alami. Pesantren Luhur Al-Husna dalam menyebarkan kedamaian untuk menjaga nilai-nilai toleransi di Surabaya tidak menggunakan hal-hal mistis untuk menyebarkan dakwah melainkan dengan cara-cara epik yang semakin membumikan nilai kerukunan antar umat beragama di surabaya. Kelima, pendakwah mampu menyampaikan pesan dakwah secara rasional. Strategi dialog yang dilakukan serta keahlian para santri untuk berdialog dengan umat agama lain adalah salah satu bukti bahwa para santri dan pengasuh mampu menyampaikan dakwah secara rasional. Keenam, dakwah yang disampaikan adalah ajaran Islam yang mampu diterima akal atau rasional. Banyaknya umat beragama yang ingin belajar bersama dari tahun ketahun menjadi bukti bahwa dakwah yang disampaikan mampu diterima akal manusia, sehingga dianggap sebuah kebenaran dan patut untuk diikuti.

Jika dikaitkan dengan strategi dakwah perspektif Al-Bayanuni dalam kitab AlMadkhal Ila Ilmu Dakwah, strategi dakwah Pesantren Luhur Al-Husna telah menggunakan metode yang ada di dalam kitab tersebut seluruhnya, yakni strategi dakwah al-athifi, al-aqly, dan al-hissi. Pada strategi al-athifi, yakni metode dengan menggerakkan perasaan dan batun mitra dakwah. Dari tiga cara penggunaan strategi 
sentimentil yakni nasehat yang baik, mendoakan, dan memberikan pelayanan, Pesantren Luhur Al-Husna menggunakaan cara yang ketiga yakni memberikan pelayanan. Terlihat dari bidang dakwah yang ditekuni oleh gerakan ini, yakni sosial dan pendidikan.

Jika dikaitkan dengan strategi al-'aqli yakni cara berdakwah yang fokus terhadap aspek akal dan pikiran, Pesantren Luhur Al-Husna menggunakan strategi persuasi, akal, dan dialog bukan kekerasan. Dialog dan berdebat yang dilakukan oleh santri dan pengasuh Pesantren Luhur Al-Husna menunjukkan bahwa strategi al- 'aqli digunakan secara baik. Terbukti dengan banyaknya orang yang berubah piikiran dan cara pandang mereka, dengan semakin damainya persaudaraan antar umat beragama dalam menjaga nilai toleransi di Surabaya hingga sekarang. Hal ini sesuai dengan ciriciri strategi al-'aqli. Dialog yang dilakukan bertujuan pula untuk melenturkan ketegangan antara agama yang ada di Surabaya. Dialog dalam berdakwah dilakukan dengan tiga hal yakni, pertama, membentuk sikap saling menghormati (tolerance). Kedua, berisi tentang penerimaan terhadap identitas orang lain. Ketiga, saling berbagi kesenian dan kebudayaan. Jika dikaitkan dengan strategi al-hissi yakni berdakwah berdasarkan pengamatan dan observasi, Pesantren Luhur Al-Husna paham, strategi mana yang harus digunakan untuk menyebarkan dakwahnya. Dengan berdakwah dalam bidang sosial dan pendidikan menunjukkan bahwa mereka menggunakan data untuk mengembangkan dakwahnya.

\section{Kesimpulan}

Strategi dakwah Pesantren Luhur Al-Husna dalam menjaga toleransi di Surabaya mengedepankan strategi dakwah yang rasional dengan mengutamakan dialog. Hal ini selaras dengan strategi dakwah yang terangkum dalam kitab Al-Madkhal Ila Ilmi Dakwah karya Al-Bayanuni, yakni strategi al-athifi, al-aqly, dan al-hissi. Dalam melaksanakan Dakwahnya Pesantren Luhur Al-Husna mampu menyelaraskan antara agama dan pengetahuan modern. Selain itu, Pesantrenn Luhur Al-Husna memiliki komitmen yang kuat untuk mempersiapkan generasi muslim yang tangguh sehingga sumber daya manusia yang ada semakin berkualitas. Strategi dakwah Pesantren luhur Al-Husna Surabaya dalam menjaga toleransi di Surabaya bisa dikatakan berhasil sehingga dapat dilihat dengan terwujudnya kerukunan, persaudaraan antar umat beragama di Surabaya yang terjalin dengan baik hingga saat ini. 


\section{Referensi}

A'la, Abd. (2005). Nilai-Nilai Pluralisme Dalam Islam. Bandung: Nuansa.

Ahmad, Nur, (2001). Pluralitas Agama “Kerukunan Dalam Keragaman”, Jakarta: Kompas.

Al-Bayanuni (2001). Muhammad. Al-Madkhal Ila Ilmi Dakwah. Ar-Risalah Beirut.

Anam. Kholi, (Ketua Pesantren Luhur Al-Husna). Wawancara. Surabaya 16 Desember 2019.

Ansari, M. Hafi, (1993). Pemahaman dan Pengamalan Dakwah, Surabaya: Al-Ikhlas.

As, Hornby. (1995). Oxford Advanced Leaner's Dictionary. Univesity Printing House: Oxford

Aziz, Moh Ali. (2015). Ilmu Dakwah. Surabaya: Kencana.

Bachtiar, Anis. (2005). "Islamisme, Westernisme serta Nasionalisme: dalam Tinjauan Sosiosiologis 3 Aliran Pembaharuan. Jurnal Pemikiran Keislaman . Vol 14 (1), 1-12. DOI: https://doi,org//10.33367/tribakti.v14i1.6.

Baidhawy, Z. (2005). Pendidikan Agama . Jakarta: Bumi Aksara.

Carrol B. Jill. (2007). “A Dialoge of Civilizations. Gulen's Islamic Ideals and Humanistic Discourse". New Jersey: The Light.

Cassanova, J. (2008). "Publice Religions In The Moderns World". Chicago University Press: Chicago.

Efendi, Uchjana. (1993). "Ilmu, Teori dan Filasafat Komunikasi". Chitra Adhitya Bhakti: Bandung.

Hasbhullah, (1996). “Khapita Selekta Pendidikan Islam”. Jakarta: PT Raja Grafindo Persada

Husniya, Yuli, (2017), "Strategi Dakwa Dr. Zakir Naik”, Lampung: Sarjana Kommunikasi dan Penyiaran Islam Universitas Negeri Raden Intan Lampung.

Jamaluddin, dkk, (2012), Pembina'an Nilai Toleransi Beragama Di Pondok Pesantren Annuriyyah Soko Tunggal Semarang. Jurusan HKn, Fakultas Ilmu Sosial, Universitas Negeri Semarang, Indonesia.

Kahmad, Dadang. (2002). Sosiologi Agama. Bandung: Rosdakarya.

Maksum, Ali. (2015), "Moddel Pendidikan Toleransi Di Pesantren Modern serta Salaf. Fakultas Tarbiyah dan Kependidikan”, Universitas Islam Negeri Sunan Ampel Surabaya.

Moesa, Ali Mascan. (Pengasuh Pesantren Luhur Al-Husna Surabaya). Wawancara. Surabaya 16 Desember 2019. 
Rahmawati, dkk, (2014) Implementasi Sikap Toleransi Beragama di Pondok Pesantren Darut Taqwa Pasuruan, Fakultas Syariah UIN Maulana Malik Ibrahim Malang.

Riyadi, H. 2007. Melampaui Pluralisme. Jakarta: RMBOOK \& PSAP.

Shadri, Ahmad, (2002), "Kata Pengantar dalam Abdul Karim Soroush, Menggugat Otoritas serta Tradisi Agama”, terjemah, Abdullah Ali, Bandung: Mizan.

Shani, Abdhul, 1998), "Lintasan Sejarah Pemikiran: Perkembangan Modern dalam Islam”. Jakarta: Raja Grafiindo Persada.

Shanjaya, Wina, (2006), "Strategi Pembelajaran Ber-orientasi Standar Prpses Pendidikan”, Jakarta: Kenchana.

Sihab, Alwi, (1998), "Islam Inklusif: Menuju Sikap Terbuka dalam Beragama", Bandung: Mizan.

Said Aqil Siradj, (2014), "Pendidikan Karakter Pesantren dan Keutuhan NKRI" dalam lbi Syatibi (edisi), Pendidikan Karakter Berbasis Tradisi Pesantren, Jakarta: Renebook.

Sukir Asmuni, (1983), "Dasar-Dasar Strategis Dalam Dakwah Islam”, Surabaya: Alikhlas

Taufiq, Abdullah. "Agama dan Masyarakat; Pendekatan Sosiologis Agama”. Jakarta: Wacana Ilmu, 1987.

Taufiqurrahman, (2009), "Sejarah Sosial Masyarakat Islam”. Surabaya: Pustaka Islamika.

Jhoacim, (1958). “The Commparative Study Of Religion”. Colombia University Press: New York.

Whalzer, Michael. (1997), “On Toleration Castle Lectures in Ethics, Polithics, and Echonomics”. Yale University Press: New York.

Yatim, (2006), “Sejarah Peradaban Islam”. Jakarta: PT Grafindo. 